\title{
HUBUNGAN TINGKAT KEPUASAN MUTU HIDANGAN DENGAN TINGKAT KONSUMSI ENERGI DAN MAKRONUTRIEN PADA REMAJA DI BPSAA PAGADEN SUBANG
}

\section{Correlation Of Satisfaction Level Of Food Quality With Energy And Macronutrient Intake In Adolescents At Bpsaa Pagaden Subang}

\author{
Gina Sela Heidi, Indah Nuraeni, Friska Citra Agustia \\ Prodi Ilmu Gizi FIKes Universitas Jenderal Soedirman \\ E-mail: ginasheidi03@gmail.com
}

\begin{abstract}
To examine the association between the level of food quality satisfaction with energy and macronutrient intake in adolescents at Balai Perlindungan Sosial Anak (BPSAA) Pagaden Subang. This was a cross sectional study included 45 respondents selected by simple random sampling. Respondents fill the questionare of the level of food quality satisfaction and recall 24 hours. Bivariate analysis used RankSpearman test. Most of respondents were satisfied with food appeareance (95.2\%), food flavor (95.7\%) and a food variation (93.3\%). The average intake of energy and macronutrients of respondents are lower than normal value (energy $=1207.15 \mathrm{kcal}$; Protein $=42.97 \mathrm{~g} ; \mathrm{Fat}=56.4 \mathrm{~g} ; \mathrm{KH}=131.90 \mathrm{~g}$ ). The results of the bivariate analysis showed no relationship between the level of food quality satisfaction with energy and macronutrient intake ( $p>0.05)$. There was no association between level of food appearance, food flavor and food variation with energy and macronutrient intake in adolescents at BPSAA Pagaden Subang.
\end{abstract}

Keywords : Food Satisfaction Level, Energy intake, Macronutrient intake, Adolescence, Ophranage

\begin{abstract}
ABSTRAK
Penyelenggaraan makanan di panti asuhan melayani anak asuh yang masih berada dalam masa pertumbuhan. Remaja memerlukan energi dan zat gizi yang lebih banyak karena pada masa tersebut merupakan masa dimana percepatan pertumbuhan dan perkembangan tubuh. Tingkat konsumsi energi dan zat gizi salah satunya ditentukan oleh kuantitas dan kualitas hidangan. Mengetahui hubungan antara tingkat kepuasan mutu hidangan sebagai salah satu output dari penyelenggaraan makanan dengan tingkat konsumsi energi dan makronutrien pada remaja di BPSAA Pagaden Subang. Desain penelitian cross sectional. Sampel sebanyak 45 remaja yang diambil secara random sampling mengisi kuesioner tingkat kepuasan mutu hidangan dan recall 24 jam. Data dianalisis menggunakan uji Rank-Spearman. Hampir seluruh responden merasa puas dengan penampilan makanan $(95,2 \%)$, cita rasa makanan $(95,7 \%)$ dan variasi makanan (93,3\%). Rata-rata asupan energi dan makronutrien responden tergolong kurang (energi $=1207,15$ Kkal; Protein $=42,97$ gr; Lemak $=56,4$ gr; $\mathrm{KH}=131,90$ gr). Hasil analisis bivariat menunjukkan tidak ada hubungan antara tingkat kepuasan mutu hidangan dengan tingkat konsumsi energi dan makronutrien ( $p>$ 0,05). Tidak terdapat hubungan antara tingkat kepuasan penampilan makanan, cita rasa makanan dan variasi makanan dengan tingkat konsumsi energi dan makronutrien pada remaja di BPSAA Pagaden Subang.
\end{abstract}

Kata Kunci : Tingkat Kepuasan Mutu Hidangan, Tingkat Konsumsi Energi, Tingkat Konsumsi Makronutien, Remaja, Panti Asuhan 


\section{PENDAHULUAN}

Balai Perlindungan Sosial Asuhan Anak (BPSAA) Pagaden Subang merupakan panti asuhan milik pemerintah yang menyelenggarakan makan secara masal untuk dibagikan kepada seluruh anak asuh sebanyak tiga kali waktu makan dan satu kali selingan.

Hampir semua penghuni BPSAA Pagaden Subang adalah remaja. Remaja memerlukan energi dan zat gizi yang lebih banyak karena pada masa tersebut merupakan masa dimana percepatan pertumbuhan dan perkembangan tubuh (Arisman, 2010). Dalam ilmu gizi diketahui bahwa energi yang dibutuhkan manusia dihasilkan oleh tiga zat gizi makro, yaitu : karbohidrat, lemak dan protein. Tingkat konsumsi energi dan zat gizi salah satunya ditentukan oleh kuantitas dan kualitas hidangan.

Kualitas makanan mencakup dua aspek utama, yaitu penampilan makanan dan rasa makanan waktu dimakan (Moehyi, 1992). Sebuah penelitian menyatakan bahwa tingkat kecukupan energi dan protein memiliki hubungan yang nyata dengan tingkat kesukaan terhadap rasa makanan (Sutyawan dan Setiawan, 2013). Penelitian lain menyebutkan bahwa untuk memenuhi kepuasan konsumen maka perlu diperhatikan cita rasa makanan dan minuman yang tersedia dan juga kesesuaian menu dan selera konsumen (Wulansari et al., 2014).

Hasil Riskesdas

menunjukan status gizi (IMT/U) remaja usia 13-15 tahun di Jawa Barat menunjukkan sebanyak $2,6 \%$ remaja berstatus sangat kurus, 6,5\% remaja berstatus kurus, $81,2 \%$ remaja berstatus gizi normal, $7,5 \%$ remaja mempunyai berat badan lebih dan $2,2 \%$ remaja berstatus obesitas. Status gizi remaja usia 16-18 tahun (IMT/U) didapatkan hasil sebanyak $1,4 \%$ remaja berstatus sangat kurus, $7,7 \%$ remaja berstatus kurus, $83,4 \%$ remaja berstatus gizi normal, $6,2 \%$ remaja mempunyai berat badan lebih dan 1,4\% remaja berstatus obesitas. Hasil studi pendahuluan yang telah dilakukan oleh peneliti terhadap 53 anak asuh remaja di BPSAA Pagaden Subang pada minggu ke -4 bulan Mei tahun 2016 menunjukkan sebanyak 2\% 
anak asuh berstatus gizi kurus, sebanyak $83 \%$ anak asuh berstatus gizi normal, dan sebanyak $15 \%$ anak asuh berstatus gizi gemuk.

Sampai saat ini, belum banyak penelitian yang mengulas tentang penilaian kepuasan mutu hidangan dan tingkat konsumsi dengan subjek remaja yang tinggal di panti asuhan. Berdasarkan uraian di atas peneliti tertarik untuk mengkaji kepuasan mutu hidangan sebagai salah satu output dari penyelenggaraan makanan institusi dan hubungannya dengan tingkat konsumsi energi dan makronutrien pada remaja yang tinggal di panti asuhan, khususnya di Balai Perlindungan Sosial Asuhan Anak (BPSAA) Pagaden Subang.

\section{METODE PENELITIAN}

Desain penelitian yang digunakan dalam penelitian ini menggunakan desain cross sectional. Penelitian ini dilakukan di BPSAA Pagaden Subang Jawa Barat. Populasi sampel adalah seluruh klien remaja yang terdaftar di BPSAA Pagaden Subang dengan jumlah besar sampel penelitian ini yaitu 45 responden yang diambil menggunakan teknik simple random sampling. Kriteria inklusi yang digunakan yaitu klien berusia 13-18 tahun, bersedia menjadi responden dan tidak sedang sakit. Sedangkan kriteria eksklusi yang digunakan yaitu klien dibawah usia 13 tahun dan di atas 18 tahun, mempunyai penyakit tertentu dan berkebutuhan khusus. Kuesioner yang dipakai yaitu kuesioner kepuasan mutu hidangan bertipe skala likert. Metode analisis yang digunakan pada penelitian ini adalah uji Rank-Spearman.

\section{HASIL DAN PEMBAHASAN}

\section{Analisis Univariat}

Hasil analisis univariat karakteristik responden disajikan pada Tabel 1, Tabel 2 dan Tabel 3. 
Tabel 1. Distribusi Frekuensi Karakteristik Responden

\begin{tabular}{|c|c|c|c|}
\hline \multirow{2}{*}{ No. } & \multirow{2}{*}{ Karakteristik } & \multicolumn{2}{|c|}{ Frekuensi } \\
\hline & & $\mathbf{N}$ & $\%$ \\
\hline 1 & Usia & & \\
\hline & a. $13-15$ tahun & 21 & 46,7 \\
\hline & b. 16-18 tahun & 24 & 53,3 \\
\hline & Total & 45 & 100,0 \\
\hline 2 & Jenis Kelamin & & \\
\hline & a. Laki-laki & 18 & 40 \\
\hline & b. Perempuan & 27 & 60 \\
\hline & Total & 45 & 100,0 \\
\hline 3 & Tingkat Pendidikan & & \\
\hline & a. SMP/sederajat & 12 & 26,7 \\
\hline & b. SMA/sederajat & 33 & 73,3 \\
\hline & Total & 45 & 100,0 \\
\hline 4 & Status Gizi & & \\
\hline & a. Kurus & 4 & 8,9 \\
\hline & b. Normal & 36 & 80 \\
\hline & c. Gemuk & 5 & 11,1 \\
\hline & Total & 45 & 100,0 \\
\hline
\end{tabular}

Distribusi frekuensi karakteristik responden berdasarkan Tabel 1 menunjukkan bahwa usia menunjukan bahwa dari 45 orang responden, sebesar $53,3 \%$ berusia diantara $16-18$ tahun, sebesar $60 \%$ berjenis kelamin perempuan, sebesar $73,3 \%$ responden berjenjang pendidkan SMA dan sebesar $80 \%$ responden berstatus gizi normal. Tabel 2 menunjukan bahwa sebagian besar responden merasa puas dengan mutu hidangan yang disajikan di BPSAA Pagaden Subang, terdapat 95,2\% responden yang merasa puas dengan penampilan makanan, $95,7 \%$ responden yang merasa puas dengan cita rasa makanan dan 93,3\% responden merasa puas dengan variasi makanan. 
Tabel. 2 Distribusi Frekuensi Tingkat Kepuasan Mutu Hidangan

\begin{tabular}{clcc}
\hline No. & \multicolumn{1}{c}{ Karakteristik } & N & \% \\
\hline $1 \quad$ Penampilan Makanan & & \\
& a. Tidak Puas & 2 & 4,8 \\
& b. Puas & 43 & 95,2 \\
& Total & 45 & 100,0 \\
2 & Cita Rasa Makanan & & \\
$\quad$ a. Tidak Puas & 1 & 4,3 \\
& b. Puas & 44 & 95,7 \\
& Total & 45 & 100,0 \\
3 & Variasi Makanan & & \\
& a. Tidak Puas & 3 & 6,7 \\
& b. Puas & 42 & 93,3 \\
& Total & 45 & 100,0 \\
\hline
\end{tabular}

Tabel. 3 Distribusi Frekuensi Tingkat Konsumsi

\begin{tabular}{|c|c|c|c|}
\hline No. & Karakteristik & $\mathbf{N}$ & $\%$ \\
\hline \multirow[t]{4}{*}{1} & Tingkat Konsumsi Energi & & \\
\hline & a. Sangat Kurang & 36 & 80 \\
\hline & b. Kurang & 9 & 20 \\
\hline & Total & 45 & 100,0 \\
\hline \multirow[t]{5}{*}{2} & Tingkat Konsumsi Protein & & \\
\hline & a. Sangat Kurang & 32 & 71,1 \\
\hline & b. Kurang & 12 & 26,7 \\
\hline & c. Baik & 1 & 2,2 \\
\hline & Total & 45 & 100,0 \\
\hline \multirow[t]{6}{*}{3} & Tingkat Konsumsi Lemak & & \\
\hline & a. Sangat Kurang & 22 & 48,9 \\
\hline & b. Kurang & 13 & 28,9 \\
\hline & c. Baik & 8 & 17,8 \\
\hline & d. Lebih & 2 & 4,4 \\
\hline & Total & 45 & 100,0 \\
\hline \multirow[t]{4}{*}{4} & Tingkat Konsumsi Karbohidrat & & \\
\hline & a. Sangat kurang & 44 & 97,8 \\
\hline & b. Kurang & 1 & 22 \\
\hline & Total & 45 & 100,0 \\
\hline
\end{tabular}

Tabel 3 menunjukkan responden dengan tingkat konsumsi energi yang sangat kurang sebanyak $80 \%$ dan responden yang tingkat konsumsi energinya kurang sebesar 20\% ; responden yang memiliki tingkat konsumsi protein sangat kurang sebesar
$71,1 \%$, responden yang tingkat konsumsi proteinnya kurang sebanyak $26,7 \%$ dan responden yang tingkat konsumsi proteinnya baik sebanyak 2,2\% ; menunjukkan responden yang memiliki tingkat konsumsi lemak sangat kurang sebesar $48,9 \%$, responden yang memiliki 
tingkat konsumsi lemak kurang sebesar $28,9 \%$, responden yang memiliki tingkat asupan lemak baik sebesar $15,5 \%$ dan responden yang memiliki tingkat konsumsi lemak lebih sebesar 6,7 ; responden yang memiliki tingkat konsumsi karbohidrat sangat kurang sebanyak $97,8 \%$ dan responden yang memiliki tingkat konsumsi karbohidrat kurang sebesar $2,2 \%$.

\section{Analisis Bivariat}

Hasil analisis bivariat antara tingkat kepuasan mutu hidangan dan tingat konsumsi energi dan makronutrien disajikan pada Tabel 4, Tabel 5 dan Tabel 6.

Tabel 4. Hubungan Tingkat Kepuasan Penampilan Makanan dengan Tingkat Konsumsi Energi dan Makronutrien

\begin{tabular}{clcc}
\hline No. & $\begin{array}{c}\text { Kategori Tingkat } \\
\text { Konsumsi }\end{array}$ & P value & Keterangan \\
\hline 1 & Energi & 0,481 & Tidak ada hubungan \\
2 & Protein & 0,370 & Tidak ada hubungan \\
3 & Lemak & 0,747 & Tidak ada hubungan \\
4 & Karbohidrat & 0,832 & Tidak ada hubungan \\
\hline
\end{tabular}

Tabel 4. menunjukkan bahwa tidak ada hubungan antara tingkat kepuasan penampilan makanan dengan tingkat konsumsi energi $(\mathrm{p}=0,481)$, tidak ada hubungan antara tingkat kepuasan penampilan makanan dengan tingkat konsumsi protein $(\mathrm{p}=$ 0,370), tidak ada hubungan antara tingkat kepuasan penampilan makanan dengan tingkat konsumsi lemak $(\mathrm{p}=0,747)$, tidak ada hubungan antara tingkat kepuasan penampilan makanan dengan tingkat konsumsi karbohidrat pada remaja di BPSAA Pagaden Subang $(\mathrm{p}=0,832)$.

Tabel 5. Hubungan Tingkat Kepuasan Cita Rasa Makanan dengan Tingkat Konsumsi Energi dan Makronutrien

\begin{tabular}{cccc}
\hline No. & $\begin{array}{c}\text { Kategori Tingkat } \\
\text { Konsumsi }\end{array}$ & P value & Keterangan \\
\hline 1 & Energi & 0,623 & Tidak ada hubungan \\
2 & Protein & 0,132 & Tidak ada hubungan \\
3 & Lemak & 0,623 & Tidak ada hubungan \\
4 & Karbohidrat & 0,882 & Tidak ada hubungan \\
\hline
\end{tabular}


Tabel 5. menunjukan bahwa tidak ada hubungan antara tingkat kepuasan cita rasa makanan dengan tingkat konsumsi energi $(\mathrm{p}=0,623)$, tidak ada hubungan antara tingkat kepuasan cita rasa makanan dengan tingkat konsumsi protein $(\mathrm{p}=0,132)$, tidak ada hubungan antara tingkat kepuasan cita rasa makanan dengan tingkat konsumsi lemak ( $\mathrm{p}=$ $0,623)$, tidak ada hubungan antara tingkat kepuasan cita rasa makanan dengan tingkat konsumsi karbohidrat $(\mathrm{p}=0,882)$ pada remaja di BPSAA Pagaden Subang.

Tabel 6. Hubungan Tingkat Kepuasan Variasi Makanan dengan Tingkat Konsumsi Energi dan Makronutrien

\begin{tabular}{cccc}
\hline No. & $\begin{array}{c}\text { Kategori Tingkat } \\
\text { Konsumsi }\end{array}$ & P value & Keterangan \\
\hline 1 & Energi & 0,382 & Tidak ada hubungan \\
2 & Protein & 0,887 & Tidak ada hubungan \\
3 & Lemak & 0,409 & Tidak ada hubungan \\
4 & Karbohidrat & 0,793 & Tidak ada hubungan \\
\hline
\end{tabular}


Tabel 6. menunjukan bahwa Tidak ada hubungan antara tingkat kepuasan variasi makanan dengan tingkat konsumsi energi $(\mathrm{p}=0,382)$, tidak ada hubungan antara tingkat kepuasan variasi makanan dengan tingkat konsumsi protein $(0,887)$, tidak ada hubungan antara tingkat kepuasan variasi makanan dengan tingkat konsumsi lemak $(p=0,409)$, tidak ada hubungan antara tingkat kepuasan variasi makanan dengan tingkat konsumsi karbohidrat $(\mathrm{p}=0,793)$.

Hasil penelitian menunjukan bahwa hampir seluruh responden merasa puas terhadap penampilan makanan $(95,2 \%)$, cita rasa makanan $(95,7 \%)$, dan variasi makanan $(93,3 \%)$. Sedangkan rata-rata tingkat konsumsi energi dan makronutriennya sangat rendah, yaitu 1207,15 Kkal (< 70\% AKG) untuk energi; 42,97 gram $(<80 \%$ AKG) untuk protein; 56,4 gram $(<80 \%$ AKG) untuk lemak; dan 131,90 gram (<80\% AKG) untuk karbohidrat. Hasil penelitian menunjukan bahwa terdapat sebagian besar responden memiliki asupan energi dan makronutrien yang rendah bila dibandingkan dengan kebutuhannya.

Rata-rata asupan energi yang didapatkan dari menu yang disediakan oleh BPSAA adalah sebesar 1483,7 kkal, sedangkan rata-rata kebutuhan energinya adalah sebesar 2132,11 kkal. Perbandingan asupan energi yang dibutuhkan dengan asupan energi yang dikonsumsi yaitu sebesar 69,6\% yang termasuk ke dalam kategori asupan energi sangat kurang. Rata-rata asupan protein yang didapatkan dari menu yang disediakan oleh BPSAA adalah sebesar 39,7 gram, sedangkan rata-rata kebutuhan proteinnya adalah sebesar 61,54 gram. Perbandingan asupan protein yang dibutuhkan dengan asupan protein yang dikonsumsi yaitu sebesar $64,5 \%$ yang termasuk ke dalam kategori sangat kurang. Rata-rata asupan lemak yang didapatkan dari menu yang disediakan oleh BPSAA adalah sebesar 84 gram, sedangkan rata-rata kebutuhan lemaknya adalah sebesar 71,5 gram. Perbandingan asupan karbohidrat yang dibutuhkan dengan asupan protein yang dikonsumsi yaitu sebesar $117,4 \%$ yang termasuk ke dalam kategori baik. Ratarata asupan karbohidrat yang didapatkan 
dari menu yang disediakan oleh BPSAA adalah sebesar 146,7 gram, sedangkan rata-rata kebutuhan karbohidratnya adalah sebesar 294,7 gram. Perbandingan asupan karbohidrat yang dibutuhkan dengan asupan karbohidrat yang dikonsumsi yaitu sebesar 49,7\% yang termasuk ke dalam kategori sangat kurang.

Hasil penelitian ini bertentangan dengan beberapa peneitian terdahulu. Penelitian Febrianti (2009) menyatakan terdapat hubungan positif yang antara tingkat konsumsi energi dengan penilaian tingkat kepuasan penampilan makanan, yang berarti semakin meningkat kualitas bentuk dan warna makanan maka semakin meningkat pula tingkat konsumsi energinya. Penelitian Liber et al. (2014) menyebutkan bahwa asupan responden yang mendapatkan makanan dengan peningkatan kualitas cita rasa memiliki konsumsi makanan dan asupan zat gizi makro lebih tinggi dibandingkan responden yang tidak mendapatkan makanan biasa tanpa peningkatan kualitas cita rasa. Lebih lanjut, Liber et al. (2014) juga menyebutkan bahwa semakin tinggi antara susunan variasi makanan kaitannya maka semakin tinggi tingkat selera makan, sehingga apabila selera makan baik, maka tingkat konsumsi juga baik.

Ketidakadaan hubungan antar ariabel dalam penelitian ini dapat disebabkan oleh berbagai hal :

1. Terdapat faktor lain yang tidak diteliti, seperti faktor internal dan faktor eksternal yang memengaruhi seseorang dalam menerima makanan. Faktor internal adalah faktor yang berasal dari diri sendiri dan hal yang berkaitan dengan nafsu makan seperti kebiasaan makan, rasa bosan, serta adanya aturan makan tertentu. Faktor eksternal yaitu faktor yang berasal dari lingkungan dan makanan yang disajikan seperti waktu pembagian makanan, cara penyajian, kebersihan alat makan, kebersihan lingkungan tempat makan (Moehyi, 1992).

2. Kemungkinan terjadi bias pada saat pengolahan data asupan gizi dimana persen kecukupan energi dan makronutrien tidak dihitung dengan 
cara menghitung tingkat kebutuhan

perindividu, melainkan dengan

membandingkan tingkat konsumsi

dengan rerata kebutuhan remaja berdasarkan AKG.

3. Kemungkinan terjadi bias dari responden pada saat pengisian kuisioner tingkat kepuasan berupa overreporting, dimana responden memberi skor kepuasan penampilan makanan lebih tinggi dari presepsi yang sesungguhnya (Supariasa et al., 2012 ).

Berdasarkan hasil recall 24 jam, diketahui bahwa tidak semua responden mengkonsumsi makanan yang telah disediakan dalam jumlah yang cukup. Selama wawancara diketahui bahwa beberapa responden terkadang melewati sarapan karena bangun kesiangan. Beberapa responden juga sering melewatkan makan siang karena biasanya sepulang sekolah, responden lebih memilih untuk tidur siang sebelum melakukan kegiatan piket Mes dan pengembangan keterampilan yang diadakan, seperti degung atau pencak silat di sore hari.

\section{KESIMPULAN}

Hampir seluruh responden sudah merasa puas dengan penampilan, cita rasa, dan variasi makanan pada penyelenggaraan makanan di BPSAA Pagaden Subang. Rata-rata asupan energi dan makronutrien responden termasuk ke dalam kategori sangat rendah, kecuali lemak Rata-rata asupan energi. Tidak ada hubungan antara variabel tingkat kepuasan mutu hidangan dengan tingkat konsumsi energi dan makronutrien. Perlu dilakukan penyuluhan pada klien di BPSAA Pagaden Subang agar dapat meningkatkan pengetahuan tentang pentingnya zat gizi dalam masa pertumbuhan dan perkembangan.

\section{PUSTAKA}

Arisman. 2010. Gizi Dalam Daur Kehidupan : Buku Ajar Ilmu Gizi Edisi 2. EGC. Jakarta.

Depkes RI. 2000. Pedoman Perbaikan Gizi di Panti Sosial Asuhan Anak (PSAA). Departemen Kesehatan Republik Indonesia. Jakarta.

Febrianti D. 2009. Penyelenggaraan Makanan, Tingkat Konsumsi dan Analisis Preferensi Atlet di SMA Negeri Ragunan Jakarta. Disertasi. Fakultas Ekologi Manusia Institut Pertanian Bogor, Bogor.

Liber, Andarwulan N, Adawiyah DR. 2014. Peningkatan Kualitas Cita Rasa Makanan 
Rumah Sakit untuk Mempercepat Penyembuhan Pasien. Jurnal Mutu Pangan, 1(2): 83-90, ISSN2 355-5017.

Moehyi S. 1992. Penyelenggaraan Makanan Institusi dan Jasa Boga. Bharata. Jakarta.

Riskesdas. 2013. Riset Kesehatan Dasar. Badan Penelitian dan Pengembangan Kesehatan. Kementrian Kesehatan RI Tahun 2013. Jakarta.

Supariasa IDN, Bakri B, dan Fajar I. 2012.

Penilaian Status Gizi. EGC. Jakarta.

Sutyawan dan Setiawan B. 2013. Penyelenggaraan Makanan, Daya Terima Makanan, Dan Tingkat Asupan Siswa Asrama Kelas Unggulan SMA 1 Pemali Bangka Belitung. Jurnal Gizi dan Pangan, 8(3): 207-214, ISSN 1978 - 1059.

Wulansari A, Setiawan B, dan Sinaga T. 2014. Penyelenggaraan Makanan dan Tingkat Kepuasan Konsumen di Kantin Zea Mays Institut Pertanian Bogor, Jurnal Gizi dan Pangan. 8(2): 1. 